\title{
Phospholipase gene expression during Paracoccidioides brasiliensis morphological transition and infection
}

\author{
Deyze Alencar Soares ${ }^{1}$, Marilia Barros Oliveira', Adriane Feijó Evangelista², \\ Emerson José Venancio ${ }^{2}$, Rosângela Vieira Andrade ${ }^{3}$, Maria Sueli Soares Felipe ${ }^{3,4}$, Silvana Petrofeza1/+ \\ 'Instituto de Ciências Biológicas, Universidade Federal de Goiás, Goiânia, GO, Brasil ²Departamento de Ciências Patológicas, \\ Universidade Estadual de Londrina, Londrina, PR, Brasil 'Programa de Pós-Graduação em Ciências Genômicas e Biotecnologia, \\ Universidade Católica de Brasília, Brasília, DF, Brasil ${ }^{4}$ Departamento de Biologia Celular, Universidade de Brasília, Brasília, DF, Brasil
}

Phospholipase is an important virulence factor for pathogenic fungi. In this study, we demonstrate the following: (i) the Paracoccidioides brasiliensis pld gene is preferentially expressed in mycelium cells, (ii) the plb1 gene is mostly up-regulated by infection after $6 \mathrm{~h}$ of co-infection of MH-S cells or during BALB/c mice lung infection, (iii) during lung infection, plb1, plc and pld gene expression are significantly increased 6-48 h post-infection compared to 56 days after infection, strongly suggesting that phospholipases play a role in the early events of infection, but not during the chronic stages of pulmonary infection by $\mathrm{P}$. brasiliensis.

Key words: host-pathogen interaction - Paracoccidioides brasiliensis - pathogenicity - phospholipases

Paracoccidioidomycosis (PCM) is an endemic systemic granulomatous mycosis in Latin America that is caused by the thermoregulated dimorphic fungus Paracoccidioides brasiliensis. Infection most likely occurs due to inhalation of airborne propagules derived from the mycelial saprophytic form of the fungus. Once in the lungs, $P$. brasiliensis cells undergo a dimorphic transition to the yeast form, an essential step for the establishment of the infection, and these cells can be contained in a granuloma or can disseminate to the rest of the body. Occasionally, the yeast cells are eradicated by the immune system (Brummer et al. 1993).

A number of potential virulence factors and events are important for the establishment of a successful infection by invasive fungi, including dimorphism, adherence to host cells, cell wall composition and enzyme production, e.g., proteases, lipases and phospholipases (PLs) (San-Blas et al. 2000, Mendes-Giannini et al. 2004). In general, PLs, which include PLA, PLB, PLC and PLD, are considered virulence factors for pathogenic fungi, including Candida albicans (Mukherjee et al. 2001) and Cryptococcus neoformans (Cox et al. 2001, Santangelo et al. 2004, Ganendren et al. 2006). We previously reported the differential expression of PLB genes during in vitro $P$. brasiliensis mycelium-to-yeast (M-Y) transition (Tavares et al. 2007) and the importance of PLB in binding and internalising yeast to macrophage surfaces (Soares et al. 2010). In addition, a PLC capable of selectively hydrolysing glycosylphosphatidylinositol (GPI) membrane anchors has been detected in P. brasiliensis

doi: 10.1590/0074-0276108062013021

Financial support: CNPq, CAPES

+ Corresponding author: petrofez@uol.com.br

Received 17 August 2012

Accepted 7 June 2013
(Heise et al. 1995). Two open reading frames with high sequence homology to phosphatidylinositol-specific PLC (plc) and PLD (pld) of Aspergillus nidulans and Aspergillus oryzae, respectively, have been identified in the $P$. brasiliensis transcriptome (Felipe et al. 2005). Although PLs (A, B1, C and D) have been identified in P. brasiliensis (Felipe et al. 2005), their potential role in virulence has not been fully defined.

To advance our understanding of the molecular role and mechanism of action of PLs in the initial steps of infection and fungal adaptation to the host, we analysed the expression of the $P$. brasiliensis genes plbl, plc and pld during infection of alveolar macrophages, during acute and chronic stages of lung infection in BALB/c mice and during the $P$. brasiliensis $\mathrm{M}-\mathrm{Y}$ transition, which is an initial and fundamental step in the infectious process.

P. brasiliensis isolate 18 (ATCC 32069) was used in all experiments. The yeast phase was maintained in vitro by sub-culturing and growing at $36^{\circ} \mathrm{C}$ on Fava-Netto medium for seven days before replating. The viability of fungal cells was determined using Janus Green B vital dye (Merck, Darmstadt, Germany). Only cells with viability greater than $90 \%$ were used. Differentiation was performed in liquid medium (Fava-Netto) by changing the culture temperature from $25-36^{\circ} \mathrm{C}$ for the M-Y transition (Silva et al. 1994). Samples were collected at $0 \mathrm{~h}, 2 \mathrm{~h}$, $6 \mathrm{~h}, 12 \mathrm{~h}, 24 \mathrm{~h}$ and $48 \mathrm{~h}$. All experiments were performed in triplicate. RNA was extracted from cells pooled from three independent experiments using the TriZOL ${ }^{\circledR}$ method (Invitrogen Corp, Carlsbad, CA, USA).

Alveolar macrophages were infected as described by Tavares et al. (2007). Extracellular and weakly adherent fungi were removed $6 \mathrm{~h}$ after infection by washing with pre-warmed RPMI-1640 tissue culture medium (Sigma Chemical, USA). Macrophages were then lysed with a guanidine thiocyanate-based solution and intact fungi were harvested by centrifugation, followed immediately by TriZOL ${ }^{\circledR}$ extraction (Invitrogen Corp, Carlsbad, CA, USA) according to the manufacturer's instructions. 
Groups of 10 male BALB/c mice (6-8 weeks old) were anaesthetised and infected i.v. with $1 \times 10^{6}$ viable yeast cells in $50 \mu \mathrm{L}$ phosphate buffered saline (Cano et al. 1997). The animals were euthanised at different times, before infection and during early $(6 \mathrm{~h}, 24 \mathrm{~h}$ and $48 \mathrm{~h}$ after infection) and late periods (56 days after infection) of infection. Total RNA was isolated from lungs pooled from five-10 animals from each group at each time point of infection using the TriZOL ${ }^{\circledR}$ method (Invitrogen Corp, Carlsbad, CA, USA). RNA $(1 \mu \mathrm{g})$ treated with RNasefree DNase I (Invitrogen Corp, Carlsbad, CA, USA) in the presence of RNase inhibitor was reverse transcribed using an oligo(dT)12-18 primer and submitted to realtime polymerase chain reaction (PCR). Amplification assays were performed with a 7900HT Sequence Detection System ABI PRISM instrument (Applied Biosystems, Carlsbad, CA, USA) in $12-\mu \mathrm{L}$ reactions containing $0.4 \mu \mathrm{M}$ each primer, $6 \mu \mathrm{L}$ SYBR Green PCR Master mix $(2 \mathrm{x})$ and $0.2 \mu \mathrm{L}$ template cDNA. After initial denaturation at $95^{\circ} \mathrm{C}$ for $10 \mathrm{~min}$, amplifications were performed for 40 cycles at $95^{\circ} \mathrm{C}$ for $15 \mathrm{~s}$ and $60^{\circ} \mathrm{C}$ for $1 \mathrm{~min}$. The following oligonucleotide primers were used (5'-3'): PLB ( $p l b l)$ [plb1F- GCAATGCAAGGGAAGAAAGA; plb1R- CGATCCGAGGAACTCTAACG], PLC ( $p l c)$ [plcF- ACCAGATCTGAACCAGCCGTTGAT, plcRTCGTCTTTCAGCTCACGCATCCAT], PLD ( $p l d)$ [pldF- TCAGGGCGTTGGAATAGCGTAAGT and pldR- ACTGGTTCATAGTTGGGAGTCGGT]. The comparative crossing threshold method (Livak \& Schmittgen 2001) employing the constitutive $P$. brasiliensis $\alpha$-tubulin gene was used to normalise the expression value of each gene of interest. Real time reverse transcription-PCR experiments were performed in triplicate for all analysed genes. Statistical comparisons were performed by ANOVA and the Tukey-Kramer test. All values are reported as the mean \pm standard error of the mean with significance assumed at $\mathrm{p}<0.01$.

Analysis of P. brasiliensis PL gene expression during the dimorphic transition - The infection process of $P$. brasiliensis is initiated by aerially dispersed mycelia propagules, which differentiate into the yeast parasitic phase in human lungs. A temperature shift from $26-37^{\circ} \mathrm{C}$ is the only condition known to trigger the $\mathrm{M}-\mathrm{Y}$ transition in P. brasiliensis. This morphogenic transition has been postulated to be important in the pathogenicity of this fungus because fungal strains that are unable to differentiate into yeast cells are not virulent (San-Blas et al. 2000, Felipe et al. 2005).

Differences in the PL transcription level during the $\mathrm{M}-\mathrm{Y}$ transition could already be observed $1 \mathrm{~h}$ after the temperature was shifted from $25-36^{\circ} \mathrm{C}$, when most cells were still in the mycelial form (A in Figure). We previously followed the different steps of the dimorphic transition and established parameters to quantify the different morphotypes that are produced during the M-Y transition, which revealed that $5 \%$ of the morphological units are already in yeast form $48 \mathrm{~h}$ after the temperature shift (Silva et al. 1994). Up-regulation of the plb1 (5.67-fold) and plc (17-fold) genes was observed in vitro as early as $1 \mathrm{~h}$ after the temperature shift from $25-36^{\circ} \mathrm{C}$, with similar transcript levels observed $24 \mathrm{~h}$ after the temperature shift as well as in the yeast stage (A in Figure). During the M-Y transition, we also observed a 2.75 -fold higher yield of pld transcripts in mycelial cells cultured at $25^{\circ} \mathrm{C}$ compared with yeast cells cultured at $36^{\circ} \mathrm{C}$ ( $\mathrm{A}$ in Figure). This finding is consistent with evidence from studies in C. albicans indicating enhanced levels of pldl transcripts during the yeast to hyphal transition, suggesting that a prominent part of the phosphatidic acid and diacylglycerol pools is produced by PLD1 and that the level of these components is important for morphological transitions under certain conditions in C. albicans (Hube et al. 2001).
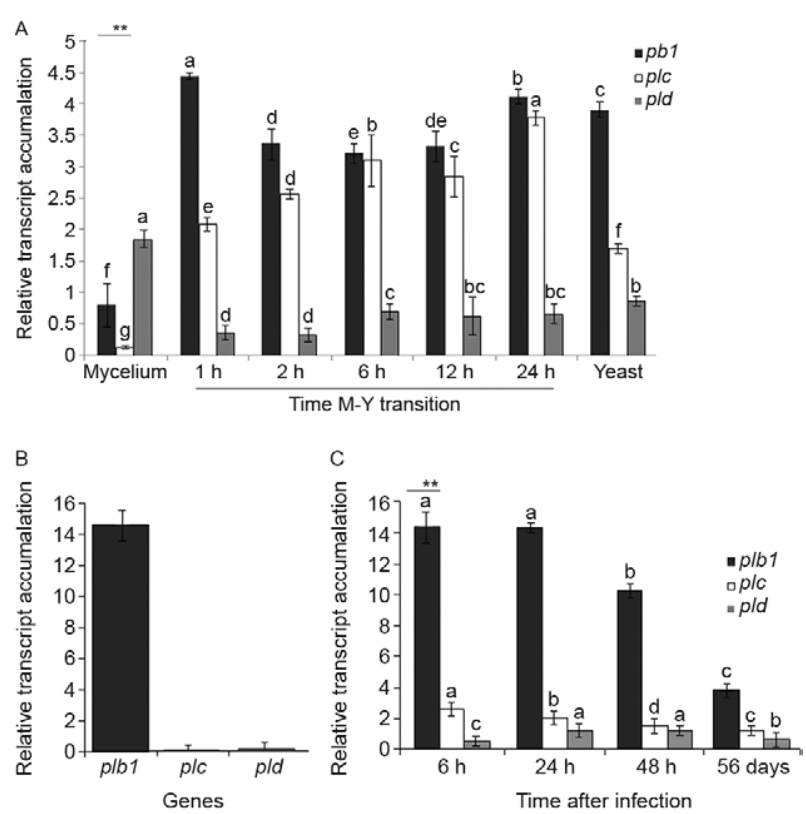

Real time reverse transcription-polymerase chain reaction. Analysis of phospholipase (PL) gene ( $p l b 1, p l c$, and pld) transcript level during Paracoccidioides brasiliensis dimorphic mycelium-to-yeast (M-Y) transition. Mycelial cells grown for $48 \mathrm{~h}$ at $26^{\circ} \mathrm{C}$ were submitted to temperature shift to $35^{\circ} \mathrm{C}$ to induce their differentiation into yeast cells. Samples were collected at $1 \mathrm{~h}, 2 \mathrm{~h}, 6 \mathrm{~h}, 12 \mathrm{~h}$, and $24 \mathrm{~h}$ and yeast cells grown at $35^{\circ} \mathrm{C}$. Results are expressed as means and standard error (SEM) of three technical replicates. RNA was isolated from pooled three independent experiments. $\triangle \mathrm{CT}$ values were used for statistical analysis (Livak \& Schmittgen 2001) using P. brasiliensis $\alpha$-tubulin gene as the internal control [**: $\mathrm{p}<0.01$ (ANOVA, Tukey-Kramer test)] (A). P. brasiliensis yeast cells $6 \mathrm{~h}$ after MH-S cell interaction. In all experiments, MH-S cells and opsonised yeast cells were incubated at a yeast-to-macrophage ratio of $1: 5$ at $37^{\circ} \mathrm{C}$ in an atmosphere of $5 \%$ $\mathrm{CO}_{2}$, as described. Results are expressed as means and SEM of three technical replicates. RNA was isolated from pooled three independent experiments. The expression of each target gene is presented as fold change normalised to the reference gene $\alpha$-tubulin and relative to the respective yeast PL genes obtain from yeast cells grown on FavaNetto medium at $35^{\circ} \mathrm{C}$ (B). P. brasiliensis yeast cells during BALB/c mice lung infection. Results are expressed as the means and SEM of three technical replicates. Five-10 mice per time point were used. The expression of each target gene is presented as fold change normalised to the reference gene $\alpha$-tubulin and relative to the respective yeast PL genes obtain from yeast cells grown on Fava-Netto medium at $35^{\circ} \mathrm{C}$ [**: $\mathrm{p}<0.01$ (ANOVA, Tukey-Kramer test)] (C). 
Phospholipase gene modulation during infection of macrophage cells and murine model by P. brasiliensis - We used a $6 \mathrm{~h}$ period for infection because this period represents an early time point of fungal cell internalisation by macrophages, as demonstrated by Tavares et al. (2007). Analysis of the gene expression of internalised $P$. brasiliensis revealed that the $p l b 1, p l c$ and pld genes were up-regulated in $P$. brasiliensis yeast cells after $6 \mathrm{~h}$ of interaction with MH-S cells compared with yeast cells cultured at $36^{\circ} \mathrm{C}$ (B in Figure).

To investigate whether the increase in PL gene expression in vitro also occurs during infection in vivo, we analysed PL gene expression during early and late infection. In the murine model, $p l b 1$ expression is higher 6-24 $\mathrm{h}$ after infection than in yeast cells cultured at $36^{\circ} \mathrm{C}(\mathrm{C}$ in Figure). Furthermore, we observed an increase in $p l c$ gene expression, while the levels of pld gene expression did not change.

Our data strongly suggest that PLB could be an important virulence factor for $P$. brasiliensis during the early events of pulmonary infection (B, C in Figure). Soares et al. (2010) reported similar observations for P. brasiliensis, confirming the participation of PLB1 in the mechanism of fungal evasion, which interferes with the host immune response. This observation is also consistent with other pathogenic fungal studies, including those of C. neoformans, in which PLB is necessary for the early events of pulmonary infection and for dissemination from the lung via the lymphatic system and blood (Ganendren et al. 2006). A similar role for plb1 may be of importance in the acute stage of PCM in mice because the infection is also contracted by inhalation.

$P$. brasiliensis infection also induces secretion of the hydrolase PLB1 in several infectious disease models (Soares et al. 2010). Previous studies have implicated secreted PLB1 in the establishment of pulmonary infection and demonstrated that it is essential for the dissemination of cryptococci to the brain and other sites (Cox et al. 2001, Santangelo et al. 2004, Ganendren et al. 2006). Cell-associated PLB1 is concentrated in lipid raft membranes, where it is attached via a GPI anchor. PLC1 regulates the release and secretion of PLB1 from its GPI anchor in the cell membrane and activates at least one signal transduction pathway (PKC/MAPK) (Chayakulkeeree et al. 2008). This observation, coupled with the enhanced levels of $p l c$ transcripts during $P$. brasiliensis lung infection, led us to conclude that PLC could have the same function in this infection model.

The relevance of PLB production in PCM is related to the fact that fungal PLB functions in the regulation of the immune response by liberating fatty acid precursors (arachidonic acid, linolenic acid or eicosanopentaenoic acid) for host eicosanoid synthesis (Noverr et al. 2003). Eicosanoids are potent regulators of host immune responses and include prostaglandins and leukotrienes produced by fungi in the lungs, which may also play a role in modulating the T-helper 1-2 balance of the immune response and promote eosinophil recruitment or survival of the fungus in the lungs (Noverr et al. 2003, Calich et al. 2008).
In conclusion, our findings strongly suggest that the PL gene family of $P$. brasiliensis is important for the pathogenesis of PCM and demonstrate that the genes of this family are differentially expressed in murine and tissue culture models.

\section{REFERENCES}

Brummer E, Castaneda E, Restrepo A 1993. Paracoccidioidomycosis: an update. Clin Microbiol Rev 6: 89-117.

Calich VLG, Pina A, Felonato M, Bernardino S, Costa TA, Loures FV 2008. Toll-like receptors and fungal infections: the role of TLR2, TLR4 and MyD88 in paracoccidioidomycosis. FEMS Immunol Med Microbiol 53: 1-7.

Cano LE, Singer-Vermes LM, Vaz CAC, Russo M, Calich VLG 1997. Pulmonary paracoccidioidomycosis in resistant and susceptible mice: relationship among progression of infection, bronchoalveolar cell activation, cellular immune response and specific isotype patterns. Infect Immun 63: 1777-1783.

Chayakulkeeree M, Sorrell TC, Siafakas RA, Wilson CF, Pantarat N, Gerik KJ, Boadle R, Djordjevic JT 2008. Role and mechanism of phosphatidylinositol-specific phospholipase $\mathrm{C}$ in survival and virulence of Cryptococcus neoformans. Mol Microbiol 69: 809-826.

Cox GM, McDade HC, Chen SC, Tucker SC, Gottfredsson M, Wright LC, Sorrell TC, Leidich SD, Casadevall A, Ghannoum MA, Perfect JR 2001. Extracellular phospholipase activity is a virulence factor for Cryptococcus neoformans. Mol Microbiol 39: 166-175.

Felipe MSS, Andrade RV, Arraes FBM, Nicola AM, Maranhão AQ, Torres FAG, Silva-Pereira, I, Poças-Fonseca MJ, Campos EG, Moraes LM, Andrade PA, Tavares AH, Silva SS, Kyaw CM, Souza DP, Pereira M, Jesuíno RS, Andrade EV, Parente JA, Oliveira GS, Barbosa MS, Martins NF, Fachin AL, Cardoso RS, Passos GA, Almeida NF, Walter ME, Soares CMA, Carvalho MJ, Brígido MM 2005. Transcriptional profiles of the human pathogenic fungus Paracoccidioides brasiliensis in mycelium and yeast cells. J Biol Chem 280: 24706-24714.

Ganendren R, Carter E, Sorrell T, Widmer F, Wright L 2006. Phospholipase B activity enhances adhesion of Cryptococcus neoformans to a human lung epithelial cell line. Microbes Infect 8: 1006-1015.

Heise N, Travassos LR, Almeida ML 1995. Paracoccidioides brasiliensis expresses both glycosylphosphatidylinositol-anchored proteins and a potent phospholipase C. Exp Mycol 19: 111-119.

Hube B, Hess D, Baker CA, Schaller M, Schäfer W, Dolan JW 2001. The role and relevance of phospholipase D1 during growth and dimorphism of Candida albicans. Microbiology 147: 879-889.

Livak KJ, Schmittgen TD 2001. Analysis of relative gene expression data using real-time quantitative PCR and the $2^{-\Delta \Delta C}$ method. Methods 25: 402-408.

Mendes-Giannini MJS, Hanna SA, Silva JLM, Andreotti PF, Vincenzi LR, Benard G, Lenzi HL, Soares CP 2004. Invasion of epithelial mammalian cells by Paracoccidioides brasiliensis leads to cytoskeletal rearrangement and apoptosis of the host cell. Microbes Infect 6: 882-891.

Mukherjee PK, Seshan KR, Leidich SD, Chandra J, Cole GT, Ghannoum MA 2001. Reintroduction of the PLB1 gene into Candida albicans restores virulence in vivo. Microbiology 147: 2585-2597.

Noverr MC, Cox GM, Perfect JR, Huffnagle GB 2003. Role of PLB1 in pulmonary inflammation and cryptococcal eicosanoid production. Infect Immun 71: 1538-1547.

San-Blas G, Travassos LR, Fries BC, Goldman DL, Casadevall A, Carmona AK, Barros TF, Puccia R, Hostetter MK, Shanks SG, 
Copping VM, Knox Y, Gow NA 2000. Fungal morphogenesis and virulence. Med Mycol 38: 79-86.

Santangelo R, Zoellner H, Sorrell T, Wilson C, Donald C, Djordjevic J, Shounan Y, Wright L 2004. Role of extracellular phospholipases and mononuclear phagocytes in dissemination of cryptococcosis in a murine model. Infect Immun 72: 2229-2239.

Silva SP, Felipe MSS, Pereira M, Azevedo MO, Soares CMA 1994. Phase transition and stage-specific protein synthesis in the dimorphic fungus Paracoccidioides brasiliensis. Exp Mycol 18: 294-299.
Soares DA, Andrade RV, Silva SS, Bocca AL, Felipe SMS, Petrofeza S 2010. Extracellular Paracoccidioides brasiliensis phospholipase B involvement in alveolar macrophage interaction. BMC Microbiol 10: 241-249.

Tavares AHFP, Silva SS, Dantas A, Campos EG, Andrade RV, Maranhão $\mathrm{AQ}$, Brígido MM, Passos-Silva DG, Fachin AL, Teixeira SM, Passos GA, Soares CM, Bocca AL, Carvalho MJ, SilvaPereira I, Felipe MS 2007. Early transcriptional response of Paracoccidioides brasiliensis upon internalization by murine macrophages. Microbes Infect 9: 583-590. 